\title{
ACERCA DOS PROCESSOS DE INDIGENIZAÇÃO DOS MUSEUS: UMA ANÁLISE COMPARATIVA*
}

Andrea Roca

\section{Introdução}

O argumento para esta apresentação decorre de observações em curso sobre a presença do museu na arena pública. Esta presença tende a tornar-se manifesta também nos domínios virtuais, mas, para o propósito deste trabalho, deixei essa dimensão deliberadamente de lado e escolhi fazer uma comparação crua, mas mutuamente iluminadora, sobre acontecimentos nas cenas museográficas brasileira e canadense, centrando-me nas experiências do Museu Magüta (primeiro museu indígena do Brasil, localizado em Benjamin Constant, Amazonas) e do Museu de Antropologia da University of British Columbia (pioneiro na implementação do trabalho colaborativo com os povos indígenas, localizado em Vancouver, Canadá). Enquanto o primeiro tem possibilitado a crescente afirmação identitária dos Ticuna, revalorizando seus saberes e tradições a par da reivindicação por terras e direitos sociais, o segundo tem estabelecido novas abordagens sobre os acervos dos povos indígenas representados em suas salas - especialmente, com o povo Musqueam - reelaborando, junto com eles, suas imagens e narrativas.

Estes projetos político-culturais parecem apontar para um sentido de modalidades coexistentes da chamada indigenização dos museus - expressão que será clarificada mais adiante. A partir da análise da presença dos índios nessas duas instituições, interessa-me distinguir as epistemologias e as políticas envolvidas na construção dos conteúdos indígenas desses espaços e sua autorrepresentação, para assim problematizar a expressão indigenização dos museus e refletir, ao mesmo tempo, sobre aquilo que se reconstrói, em termos dos cenários museológicos, após as situações coloniais.

Para isso, na primeira parte deste artigo abordarei a constituição do Museu Magüta em relação à história do povo Ticuna e suas lutas pelo reconhecimento dos seus direitos, principalmente territoriais. Sob as mesmas diretrizes, na segunda parte, apresentarei as negociações e as exposições 
realizadas pelo povo Musqueam no Museu de Antropologia da cidade de Vancouver. Por último, na terceira parte, centrar-me-ei na definição da chamada indigenização dos museus e nos processos a ela vinculados, analisando, nessas duas instituições, as semelhanças e as diferenças desses processos, ativados pelos indígenas como resultado de ações políticas concretas e situacionais.

\section{O Museu Magüta e o povo Ticuna ${ }^{1}$}

A razão de ser e as propostas do Museu Magüta vão bem mais além de um conjunto de vitrines que exibem a cultura material dos Ticuna, e seria impossível - ou melhor, seria completamente inexato e pobre - falarmos dele sem nos referirmos à história e aos fundamentos que nortearam sua criação, aos propósitos que o mobilizaram e às pessoas e às circunstâncias que, até hoje, o mantêm em pé. Como veremos a seguir, o Magüta nasceu e cresceu articulado às estratégias políticas desenvolvidas pelos Ticuna ao longo de sua história (Pacheco de Oliveira 2012:217), razão pela qual qualquer apresentação sobre ele deve necessariamente considerar também o entramado político de contextos, fatos e atores sociais envolvidos na sua projeção, mise en scène e trajetória.

O povo Ticuna — fundador e proprietário do Museu Magüta — habita a região do Alto Solimões, na tríplice fronteira com Peru e Colômbia. O museu está localizado na pequena cidade de Benjamin Constant, a $1.118 \mathrm{~km}$ de Manaus (capital do estado do Amazonas), e constitui um ponto de acesso a 11 das terras ticuna, conectando suas populações nesses três países.

Os Ticuna são o povo indígena mais numeroso da Amazônia e do país em geral, com uma população aproximada de 36.400 pessoas no Brasil, 8.000 na Colômbia e 7.000 no Peru (Instituto Socioambiental; doravante, ISA $^{2}$ ). No território brasileiro, moram nas mais de 100 aldeias distribuídas pelos oito municípios do estado do Amazonas que fazem parte da região do Alto Solimões; também habitam em centros urbanos, tais como Benjamin Constant, São Paulo de Olivença, Beruri e Manaus.

Os primeiros contatos com os brancos e a primeira referência escrita sobre eles remontam ao século XVII, quando jesuítas espanhóis, vindos do Peru, criaram uma série de aldeamentos às margens do rio Solimões (Pacheco de Oliveira 2002:280). Depois de sucessivas lutas entre espanhóis e portugueses pela hegemonia nesses territórios, no século XVIII, Portugal acabou vencendo e, como resultado desses enfrentamentos, o povo Omágua, inimigo dos Ticuna, resultou praticamente exterminado. Entretanto, os 
portugueses não ocuparam as terras que pertenceram aos Omágua e que, a partir daquele momento, tornaram-se posse dos Ticuna - que anteriormente as tinham abandonado fugindo daquele povo (ISA 2014).

Nas últimas décadas do século XIX, a região constituiu-se em um dos alvos da exploração da borracha. A empresa seringalista e seus "patrões", vindos em sua maioria do Nordeste, invadiram essas terras e instalaram-se nas bocas dos principais igarapés, deslocando e dispersando os índios em função da desenfreada extração daquele ouro branco, fragmentando famílias inteiras e lhes impondo um regime brutal de trabalho. A posterior decadência da febre da borracha não modificaria essas relações de produção (Pacheco de Oliveira 2012a:202-203).

Em 1943, a instalação de um posto indígena do Serviço de Proteção aos Índios (doravante, SPI) na localidade de Tabatinga trouxe algumas mudanças positivas para os Ticuna, impondo alguns direitos básicos, tais como a liberdade de comércio e a proibição de castigos corporais. ${ }^{3}$ Entretanto, devido à mobilização dos seringalistas, as iniciativas econômicas e políticas daquele posto indígena acabariam sendo reprimidas. As verdadeiras transformações começariam a se sentir a partir da década de 1970, quando a Fundação Nacional do Índio (Funai, a agência indigenista que substituiu o antigo SPI) encomendou a antropólogos ${ }^{4}$ um programa de proteção e assistência aos Ticuna, levando até os seringais o reconhecimento dos seus direitos e instalando seis novos postos indígenas (Pacheco de Oliveira 2012a:203-204).

Em 1980 teve lugar a primeira assembleia geral do povo Ticuna organizada pelos "capitães" — isto é, os líderes das aldeias — com o propósito de definir as terras de que precisavam, criar ações para proteger sua língua e sua cultura, e gerar soluções para seus problemas de saúde (Pacheco de Oliveira 2012a:205; Fernandes 1999). A notícia sobre esta assembleia foi divulgada através do jornal Magüta, organizado em função deste evento. $\mathrm{Na}$ sua capa estava reproduzido o desenho sobre o mito Ticuna da origem dos homens, sendo o primeiro número de uma série de 33 jornais que circularam durante 13 anos como veículo de informação entre eles (Pacheco de Oliveira 2012a:204). "Magüta" é uma denominação ancestral que, referindo-se a seu mito de criação, significa "povo pescado por Yoi" (Paladino 2006:3). Recuperando a grandeza dos antepassados, este nome era aplicado a um projeto político contemporâneo (Pacheco de Oliveira 2012a:204). Segundo este autor, "Tais episódios marcaram o início da mobilização dos Ticuna pela demarcação de suas terras, tanto no plano local quanto em nível nacional" (:204).

Durante a década de 1980, no entanto, essa constante e intensa mobilização política foi acompanhada por uma crescente hostilidade contra eles: os Ticuna sofreram ameaças, ataques armados, prisões, espancamentos e 
mortes. A magnitude desses enfrentamentos evidenciava o interesse de antigos "patrões", posseiros, madeireiros, comerciantes e até políticos locais em amedrontá-los, para assim impedirem a demarcação das suas terras.

Depois de várias reuniões entre lideranças, na segunda assembleia geral (celebrada em Belém de Solimões, em 1982), foi criado o Conselho Geral da Tribo Ticuna (CGTT), a primeira organização indígena de escala local a funcionar no Brasil. Através do CGTT, os Ticuna articulariam sua vigorosa luta pela autodeterminação e pelo reconhecimento dos seus direitos territoriais, assim como as questões vinculadas à saúde e à educação. ${ }^{5}$

Três anos mais tarde (1985), através de um projeto do Ministério da Cultura no qual participavam pesquisadores do Museu Nacional (UFRJ), os Ticuna editaram Torü Dü̈'Üguü ("Nosso Povo"), um livro que contava sua "história verdadeira" através dos seus mitos e com suas próprias ilustrações. Na contracapa, dois dos fundadores do CGTT explicavam a importância desta obra:

Dentro deste livro os Ticuna vão encontrar as histórias dos antigos, do tempo passado. Está aí a história de Yoi e do Ipi. Como eles criaram o povo Magüta, que foi o povo do princípio do mundo. O povo que estava aqui antes mesmo do branco existir [...] A gente nunca teve um livro assim antes. Aqueles que irão estudar nele deverão acordar, deverão saber por que ele foi feito. O livro saiu porque nós estamos renascendo. Foi bom porque foi feito por nós mesmos. Hoje os bisnetos, os novos, vão ver que os Ticuna têm razão de existir, porque neste livro aparece onde está a terra imemorial, o local sagrado, o local da nossa origem. Onde Ticuna nasceu, aí ele tem de ficar. O livro vai ser bom pra gente lembrar, pra gente lutar pra ser dono de novo da terra (Pedro Inácio Pinheiro e Adércio Custódio Manoel; Índios Ticuna 1985: contracapa; grifos meus).

Enquanto isso, o processo de delimitação de suas terras experimentava avanços e retrocessos. Em 1986 foram reconhecidos apenas quatro territórios pequenos, próximos à cidade de Benjamin Constant; apesar de ter sido uma conquista, tratava-se de espaços conflituosos onde a população indígena era menor do que em outras áreas, e onde também viviam numerosas famílias de madeireiros e posseiros que se recusavam a sair de lá (Pacheco de Oliveira 1996). Nesse mesmo ano, algumas lideranças do CGTT viajaram para Brasília, com o objetivo de discutir com a Funai a demarcação das áreas chamadas Évare I e II, consideradas pelos Ticuna como seus territórios tradicionais, e onde moravam aproximadamente $80 \%$ das suas comunidades.

Paralelamente, uma equipe de pesquisadores do Setor de Etnologia e Etnografia do Museu Nacional (SEE/MN), sob a coordenação de Pacheco 
de Oliveira, criou o Magüta: Centro de Documentação e Pesquisa do Alto Solimões (CDPAS), com o apoio das lideranças indígenas. Chamado geralmente "Centro Magüta", foi constituído como uma entidade civil sem fins lucrativos, cujo objetivo principal era promover iniciativas que permitissem a divulgação e o fortalecimento da cultura ticuna (ABA 2009). ${ }^{6}$ Foi instalado numa pequena casa em Benjamin Constant, tornando-se "um local de articulação entre as lideranças indígenas em suas passagens pelas cidades" (Pacheco de Oliveira 2012a:207).

Através do Centro Magüta, ainda em dezembro desse ano foi criada a Organização dos Professores Ticuna Bilíngues (OGPTB), com o intuito de realizar cursos de reciclagem e formação de professores. ${ }^{7}$ Dirigida pelo ticuna Nino Fernandes, nas sucessivas reuniões foram se discutindo os critérios que orientariam essas escolas: deviam ser dirigidas por eles próprios, sem a intervenção dos professores brancos.

Outro fato a destacar foi o apoio que o Centro Magüta recebeu de duas agências filantrópicas, a ICCO (Holanda) e OXFAM (Brasil), adquirindo por isso um terreno onde foi construída uma nova sede do Centro. Por sua vez, a agência italiana "Amigos da Terra" financiou a instalação de 15 radiotransmissores nas aldeias mais ameaçadas pelos invasores, que assim puderam se manter em contato diário com o Centro Magüta (Pacheco de Oliveira 2012a:210). Mais tarde (1988), uma parceria com a Faculdade de Medicina da UFRJ deu início à Organização dos Monitores de Saúde do Povo Ticuna (OMSPT), cujo propósito está expresso em seu nome.

Enquanto isso, devido à resistência de madeireiros e posseiros para sair das quatro pequenas áreas indígenas já demarcadas, em 25 de março de 1988 a Funai começou a divulgar, através da rádio local, as instruções para esses invasores comparecerem nas sedes locais da agência indigenista e apresentarem a documentação necessária para, caso tivessem feito benfeitorias nessas terras, receberem as indenizações correspondentes. Houve desacordos com os montantes dessas indenizações, e os funcionários da Funai foram ameaçados; entretanto, a reação mais violenta foi dirigida contra os Ticuna. Um antigo "patrão" que, conforme as disposições da Funai, teve que retirar sua mercadoria desses territórios, mandou atacar - através de 20 dos seus empregados, e com a cumplicidade de comerciantes e políticos locais - um grupo de ticunas que vinham em procissão religiosa, conformado por homens, mulheres, idosos e crianças. Os atacantes assassinaram 10 deles, enquanto outros 23 foram feridos. ${ }^{8}$ Apesar da magnitude dessa carnificina, os Ticuna tiveram que lutar para que as autoridades reconhecessem o crime e prendessem os assassinos. ${ }^{9}$ Esse ataque ficou tristemente conhecido como o "Massacre do Capacete", e teve repercussões tanto nacionais quanto internacionais. 
As provocações e as agressões contra os índios tinham chegado a um nível de acirramento extremo, tornando-se necessário implementar "mecanismos eficientes de reversão" (Pacheco de Oliveira 2012a:210). Foi assim que se começou a projetar, no Centro Magüta, a criação de um museu sobre a cultura ticuna: uma instituição e/ou instrumento "branco", mas ajustado às suas necessidades, e orientado por sentidos definidos por eles. ${ }^{10}$

Para tal fim, na frente do terreno do Centro foi construída uma casa simples de alvenaria; não obstante, naquele ambiente adverso de 1988, só foi possível inaugurar uma biblioteca, "que dispunha de livros, revistas e xerox com uma ampla documentação sobre os Ticunas e a região do Alto Solimões" (Pacheco de Oliveira 2012a:210). Única nessa região, ao longo do tempo essa biblioteca foi reunindo literatura e registros visuais sobre o povo Ticuna, a documentação histórica produzida sobre as lutas desenvolvidas pelo CGTT, e a história da região do Alto Solimões. À biblioteca chegavam professores e estudantes das escolas da rede pública que, vencendo seus preconceitos, conseguiam se aproximar do Centro para suas pesquisas escolares (Bessa Freire 2003; ABA 2009; Pacheco de Oliveira 2012a; Magüta 2014).

Paralelamente, o CGTT começou um "processo de captação de peças etnográficas, dando origem ao acervo do Museu Magüta" com o apoio de agências filantrópicas da Holanda e da Inglaterra (Pacheco de Oliveira 2002 apud Faulhaber 2005:114). Como explica Nino Fernandes, presidente do CGTT e diretor do Museu Magüta desde 1996, "Aos poucos incentivamos as comunidades a participar, a enviar artesanato" (Fernandes 2011). A notícia do museu foi espalhada pelas aldeias, e os Ticuna começaram a reunir seus objetos, construindo alguns deles especialmente para as exposições. Também realizaram pesquisas sobre as peças, definindo-as, e intervieram nas ilustrações que ajudavam a contextualizá-las. ${ }^{11}$ Segundo o historiador José Ribamar Bessa Freire (2003:221), antes da montagem final, a coleção já contava com 420 objetos. Estes foram acompanhados por fotografias do acervo dos pesquisadores do Centro Magüta e por descrições sobre os Ticuna presentes na literatura antropológica - principalmente extraídas das obras de Curt Nimuendajú (1952) e Roberto Cardoso de Oliveira (1964). Tanto as instalações quanto a montagem e o roteiro do material apresentado foram projetados conjuntamente pelos pesquisadores do Centro, as lideranças e os professores indígenas. Estes tinham tido a oportunidade de visitar o Museu Nacional do Rio de Janeiro em várias ocasiões, conhecendo suas exposições e reservas técnicas, e avaliando, através dessas experiências, a maneira com que queriam projetar o seu próprio museu (Pacheco de Oliveira 2012a:211), dando-lhe forma a partir dessas visitas e circulações mútuas.

Além de contribuir para o conhecimento e a valorização da cultura ticuna para eles próprios e para o resto da sociedade, os materiais coletados 
também testemunhavam a sua presença nas terras demandadas pelos latifundiários madeireiros e pelos seringueiros da região (Pacheco de Oliveira 2012a:211; Bessa Freire 2003:221).

Ocupando cinco salas de exposição, o museu começou a funcionar em 1991, "sem grandes alardes e sem uma inauguração formal. O museu ticuna de Benjamin Constant não se distinguia de modo algum das outras atividades do CDPAS [Centro Magüta] e só veio a receber uma placa muitos anos depois" (Pacheco de Oliveira 2012a:211) ${ }^{12}$ Começou a ter visibilidade logo no início, ${ }^{13}$ atraindo as visitas de estudantes de Ensino Fundamental e Médio (brasileiros, colombianos e peruanos) que consultavam sua biblioteca e que até hoje frequentam suas exposições; também foi e é visitado por pesquisadores, população regional não indígena, turistas de diferentes nacionalidades e pelas escolas indígenas próximas à cidade de Benjamin Constant (Paladino 2006:3; ABA 2009; Magüta 2014). Atualmente, nas instalações do museu são realizados reuniões, cursos e outras atividades, dos quais participam caciques e lideranças, professores bilíngues, agentes de saúde indígenas, monitores ambientais e mulheres artesãs (ABA 2009; Magüta 2014).

Apresentando o Museu e o Centro como algo inseparável, em 1994 o capitão geral Pedro Inácio Pinheiro, dirigente do CGTT, expressava:

O Museu do Centro Magüta é importante para nós, porque nele vai ficar guardada a cultura do nosso povo, para o futuro dos nossos filhos e netos. É importante, também, para os brancos conhecerem nossa arte, nossa ciência, para compreenderem que os Ticuna são gente que tem história, que tem cultura, que tem sua própria língua, como qualquer outro povo que existe no mundo. Para os Ticuna, o Centro Magüta é como a nossa terra sagrada, o Evaré (apud Benzi Grupioni 1994:270; grifo meu).

Enquanto isso, as mudanças ocorridas no quadro geral da política indigenista brasileira na década de 1990 trouxeram transformações significativas para os Ticuna. No contexto da ECO-92, o novo presidente da Funai naquele momento, Sidnei Possuelo, assinou o reconhecimento de dezenas de terras indígenas - entre elas, os territórios ticuna. Em face desta decisão, o próprio governador do Amazonas e políticos locais se declararam contra a demarcação das terras indígenas e, em Benjamin Constant, foram realizadas várias manifestações que apontavam para o Centro Magüta, circulando ameaças sobre sua destruição e incêndio (Pacheco de Oliveira 2012a:211).

No entanto, apesar da confirmação da demarcação das terras ticuna pela Funai, esta agência não dispunha de orçamento suficiente para levá-la 
a cabo, razão pela qual, ainda durante a ECO-92, dirigentes do CGTT e do Centro Magüta entrevistaram-se com o primeiro ministro austríaco à procura de um subsídio para financiar o projeto de demarcação fundiária. A proposta foi aceita pelo governo da Áustria e anunciada publicamente no percurso da ECO-92. Através de um triplo convênio entre o Centro Magüta, a Funai e uma agência austríaca de cooperação internacional (Vienna Institute for Development and Cooperation — VIDC), em 1993 foram demarcados quase 1 milhão de hectares de terras ticuna, num projeto que demandou meio milhão de dólares.

Podemos nos deter nesta conquista e sublinhar que, se até a década de 1980 os Ticuna tinham sido submetidos politicamente, vivendo como empregados explorados nos seringais, sem terras e tratados como intrusos nos seus próprios territórios, a luta conjunta dos dirigentes do CGTT e do Centro Magüta mudaria para sempre a trajetória deste povo indígena e seu lugar na nação brasileira. Esses processos de reconhecimento fundiário e as mobilizações para serem reconhecidos por parte do Estado como povo com direitos específicos foram viabilizados e concretizados no Centro Magüta, isto é, no espaço onde também funcionava o Museu.

Entretanto e como aponta Pacheco de Oliveira (2012a:214), esse novo panorama acarretaria outros desafios. Sentindo-se mais fortalecidos, foram aparecendo novas organizações indígenas ticuna com diferentes orientações, criando-se, ao mesmo tempo, rivalidades por lideranças e por controle de verbas de projetos. Por outro lado, uma vez concluída a demarcação, tiveram que ser reduzidos os postos de trabalho (diminuição que, inevitavelmente, era resultado da redução das verbas das agências financiadoras para esse fim). Isto provocou fortes críticas e descontentamentos, o que levou, em 1996, à separação radical da OGPTB do Centro Magüta. O desentendimento entre as instituições gerou uma completa ruptura política entre elas, que passaram a trabalhar a partir desse momento em espaços e contextos distintos (Pacheco de Oliveira 2012a:215). Nessa separação, os membros da OGPTB retiraram do Centro Magüta materiais didáticos, arquivos, mobiliário e todos os livros da biblioteca, considerando-os seus. ${ }^{14}$

Após esta cisão, houve versões de que o Museu Magüta tinha fechado (veja-se, por exemplo, Bessa Freire 2003:223-4). No entanto, a realidade era outra. Com a retirada dos membros da OGPTB, o CGTT assumiu por completo a responsabilidade do Centro Magüta e do Museu. Mas devido a crises financeiras, em 1997 os capitães das aldeias decidiram-se pela dissolução do Centro Magüta e por fazer a doação de todo o patrimônio desta entidade para o CGTT, que passou a ocupar a sede do museu. ${ }^{15}$ A CGTT conseguiu manter o museu aberto graças à organização de diver- 
sos capitães que, alternando-se entre eles (e às vezes até mudando-se com suas próprias famílias para Benjamin Constant), tomaram conta do museu de forma permanente. ${ }^{16}$

Como dissemos anteriormente, desde 1996 o Magüta está sob a direção de Nino Fernandes. Fazendo uma breve retrospectiva que consegue dar conta da função social específica deste museu, em 2011 ele manifestava que

Os indígenas não podiam chegar perto do porto das cidades que eram rejeitados e perseguidos. Não éramos respeitados e ainda éramos tratados como animais [...] Por isso, as lideranças viam no museu uma iniciativa pra mostrar a cultura e adquirir o respeito da população. [...] Hoje, muitos filhos daqueles que antes agiam contra os indígenas procuram o museu. Até a esposa de um dos líderes do Massacre do Capacete hoje faz pesquisa sobre os Ticuna (Fernandes 2011. Acesso em 04/02/2014).

Testemunhando a presença do constante trabalho coletivo envolvido no Magüta, também afirmava que "Hoje tem muitas comunidades contribuindo com material que é vendido aqui [em Benjamim Constant] e distribuído para Manaus" (Fernandes 2011. Acesso em 04/02/2014). No sítio web do Magüta, somos informados que ele

possui uma rica e extensa coleção de objetos relativos aos mais variados aspectos da cultura material do povo Ticuna, exibida segundo uma museografia delineada pelos próprios indígenas. Todo o museu foi projetado, mantido e dirigido exclusivamente pelos "caciques" (chefes de comunidades), articulados no Conselho Geral da Tribo Ticuna - CGTT, criado em 1982 (Magüta 2014; grifo meu).

Sublinhando a estreita ligação histórica e presente entre o CGTT e o museu, também afirmam muito claramente que este último tem participado "de forma direta e ativa de todos os acontecimentos importantes na história recente dos Ticunas" (Magüta 2014).

Por outro lado e como aponta Bessa Freire (2003:224), o Magüta também permitiu que índios e não índios entrassem pela primeira vez em um museu: conforme a enquete realizada por duas museólogas ${ }_{1}{ }^{17}$ a maioria da população não indígena de Benjamin Constant nunca tinha visto um museu, razão pela qual acreditavam que a instituição museológica era de origem ticuna.

Por último, achamos importante destacar aqui que, em 1995, o Museu Magüta foi premiado pelo International Council of Museums (ICOM) como "Museu Símbolo" desse ano. Em 1999, sua coleção foi exibida no Tropenzmuseum de Amsterdã; em 2007, Nino Fernandes recebeu a Comenda da 
Ordem do Mérito Cultural através do presidente Lula e, em 2008, o prêmio Chico Mendes, outorgado pelo Ministério do Meio Ambiente (ABA 2009). Ao longo da sua existência, o Magüta também tem estabelecido parcerias importantes com organismos governamentais; além das já mencionadas, estão aquelas com o Ministério da Educação (MEC), o Ministério da Cultura (MinC), o Ministério do Meio Ambiente (MMA), a Universidade Federal da Amazônia (Ufam) e a Fundação Nacional da Saúde (Funasa).

\section{O Museum of Anthropology (MoA) e o povo Musqueam ${ }^{18}$}

Localizado atualmente no campus universitário da University of British Columbia (doravante, UBC) - dentro da terra tradicional, ancestral e não cedida do povo indígena Musqueam ${ }^{19}$ — este museu universitário de antropologia se autodenomina "um lugar das artes e culturas do mundo", e constitui um dos principais pontos turísticos da cidade de Vancouver.

No momento da sua criação (1947), ocupou o térreo da Biblioteca Principal dessa universidade, contando com um acervo conformado por materiais provindos de pesquisas etnográficas no Pacífico Sul. Em 1971, verbas governamentais permitiram a construção do prédio atual, projetado pelo famoso arquiteto canadense Arthur Erickson (1924-2009) e inspirado pelas estruturas de postes e vigas próprias da arquitetura dos indígenas da Costa Noroeste do Pacífico. Foi inaugurado em 1976, pouco tempo depois de ter recebido a doação de uma importante coleção de cultura material sobre esses povos. ${ }^{20}$ Naquele momento, o museu estava sob a direção do antropólogo Michael Ames (1933-2006). Durante seu período como diretor (1974-1997), Ames transformaria o MoA no líder da nova museologia (documentada no seu paradigmático trabalho Cannibal tours and glass boxes, 1992), e em um pioneiro em trabalhos colaborativos entre museus e First nations. ${ }^{21}$

Habilitando tecnologias digitais para a participação, o povo indígena Stó:lō, o centro cultural Kwakiutl U'Mista Cultural Society, o povo Musqueam e o MoA têm desenvolvido conjuntamente, desde 2010, a Rede de Pesquisa Recíproca (Reciprocal Research Network - RRN), uma rede virtual para aceder às coleções sobre os povos indígenas da Costa Noroeste, localizadas atualmente em diferentes museus do mundo. ${ }^{22}$

Segundo o catálogo digital do MoA (MoACAT), o acervo total deste museu é de aproximadamente 40.000 objetos. Entre estes, 145 são patrimônio dos Musqueam. 


\section{a) $O$ povo indígena Musqueam ${ }^{23}$}

Os Musqueam têm suas origens em um grupo cultural mais abrangente, conhecido como Coast Salish. Na sua língua nativa - Halkomelen - a palavra "Musqueam" significa "povo da grama do rio", evidenciando o estreito laço histórico com o rio Fraser, coração e alma deste povo.

Até julho de 2011, os Musqueam somavam 1.247 pessoas. ${ }^{24}$ A maioria vive em três reservas situadas na área metropolitana de Vancouver, enquanto o resto mora nos centros urbanos mais próximos. Essas três reservas constituem uma parte muito pequena do seu território tradicional (só 254,2 ha), cuja totalidade (144.888 ha) compreende uma porção da atual cidade de Vancouver e suas áreas circundantes, ${ }^{25}$ estendendo-se para o noroeste até Howe Sound e, no nordeste, até Fraser Valley. As pesquisas arqueológicas têm identificado a existência de 161 sítios musqueam nessas áreas, demonstrando sua ocupação e seu uso há mais de 9.000 anos (Musqueam people 2012).

Os Musqueam comerciaram e construíram redes de parentesco com outras nações indígenas da atual província da British Columbia (doravante BC, no Canadá) e do estado de Washington (nos Estados Unidos). Os primeiros contatos com os brancos remontam a 1791-1792, quando navios espanhóis e ingleses chegaram a essas praias ${ }^{26}$ procurando escravos e recursos principalmente, peles e tecidos. Entre aqueles invasores, o escocês Simon Fraser (1776-1862, empregado da North West Company para o comércio de peles) realizaria a primeira expedição de reconhecimento desse território, percorrendo a boca do atual rio Fraser em 1808. Até hoje essa região tem sido a maior fornecedora de salmão de toda a Costa Noroeste, sendo o recurso mais importante da economia musqueam.

As mudanças mais significativas para este povo chegariam na segunda metade do século XIX, quando tiveram lugar os primeiros assentamentos brancos em suas terras: em 1858 foi encontrado ouro na região atualmente conhecida como Fraser Canyon, desencadeando a procura frenética deste mineral. Alegando defender esses territórios dos possíveis ataques dos Estados Unidos, os Royal Engineers (corpo integrante da Armada Britânica) instalaram-se neles entre 1858-1859, registrando-os e dividindo-os em lotes, sem nunca considerá-los como propriedade dos Musqueam.

No entanto, foram os acontecimentos entre 1870 e 1899 que trouxeram as maiores transformações para eles, que sentem seus efeitos até hoje. Em primeiro lugar - e como todos os povos indígenas do Canadá - a partir de 1876 os Musqueam passaram a ser governados pelas diretrizes do chamado Indian Act. Com o objetivo de "assimilá-los", esta lei teve o poder de definir seu status indígena e de encurralá-los e controlá-los dentro das 
chamadas reservas (pequenas e insuficientes para cobrir as suas necessidades), substituindo seus diferentes sistemas de governo pelos "Conselhos de Bandos" (Bands Councils). ${ }^{27}$

Em segundo lugar, em 1879 começaram a funcionar as chamadas escolas residenciais. Seguindo a política da "geração perdida" — comum em todo o espaço imperial britânico — essas escolas estavam encarregadas de "matar o índio que há nas crianças". ${ }^{28}$ Estas eram arrancadas das suas famílias e levadas para localidades distantes, com o objetivo de que abandonassem suas culturas e tradições para serem educadas no cristianismo, aprenderem o inglês ou o francês como única língua e acabarem "assimiladas" na civilizada identidade canadense. Calcula-se que mais de 150.000 crianças tenham sido assistidas por esta política. Muitas delas morreram dentro das escolas, enquanto tantas outras foram abusadas - psicológica, física e sexualmente. As crianças musqueam frequentaram essas instituições a partir de $1908{ }^{29}$

No plano econômico houve um importante incremento de fazendeiros, erguendo cercas e impedindo o acesso dos Musqueam a sítios específicos. Paralelamente, a chegada da tecnologia da pesca e dos enlatados os expropriaria dos seus próprios rios. Junto com outros povos indígenas, os Musqueam foram empregados durante os primeiros anos dessas indústrias, mas sem jamais deixar de disputar os direitos de pesca. Em 1888, o governo instituiu o sistema de food fishery para os índios - podendo pescar só para consumo pessoal - e de commercial fishery para os brancos - isto é, pesca comercial e suas indústrias derivadas.

A partir da década de 1920, o vertiginoso crescimento da urbanização obrigou-os a restringir ainda mais o uso tradicional dos seus próprios territórios; por outro lado, começaria um progressivo declínio da existência do salmão. Durante séculos, os Musqueam tinham sabido usar e conservar o estoque de salmão do rio Fraser; entretanto, a exploração deste peixe pelos brancos acarretaria um desequilíbrio ecológico, diminuindo também as possibilidades de emprego. ${ }^{30}$ Estas circunstâncias se enquadravam na situação mais geral do crescimento da pobreza nas reservas, pelo fato de terem sido isoladas da mais ampla economia canadense. No período 1914-1951, também foi declarado ilegal usar roupas tradicionais ou cerimoniais.

Se morando nas reservas tornava-se difícil sustentar suas famílias, viver fora delas implicava enfrentar a discriminação e a assimilação nas cidades, perdendo seu status indígena e, portanto, as conexões com as suas famílias e os seus territórios. Apesar das adversidades e das injustiças das reservas, estas acabaram se tornando espaços de referência e/ou sobrevivência cultural.

Todas as mudanças advindas do contato com os brancos estiveram acompanhadas por uma brutal dizimação da população musqueam: calculada, 
no momento do contato, em umas 30.000 pessoas, as epidemias de varíola e sarampo (1862) e as outras consequências do impacto (tais como más condições de trabalho, as escolas residenciais, a fuga das reservas etc.) chegaram a reduzir a população a só 100 pessoas (veja-se Musqueam people 2011:39).

Entretanto, durante os últimos 50 anos os Musqueam têm demonstrado sua força e conseguido muitas conquistas, exibindo sua identidade com total orgulho (ver Musqueam Declaration 1976) ${ }^{31}$ Entre as First Nations, eles são pioneiros nas demandas ao governo federal, na luta pelo reconhecimento e a proteção legal dos direitos indígenas (Seção 35 da Constituição), na comprovação de direitos a terra preexistentes ao Canadá como país (Musqueam Comprehensive Land Claim 1984), no restabelecimento dos direitos à pesca comercial (1990), na eleição de chefes mulheres (1997), e nas indenizações governamentais pelo uso e/ou apropriação indevida das terras indígenas (2008). ${ }^{32}$

Também foram pioneiros em compreender que, na luta pelo direito à autorrepresentação, o espaço museológico podia se tornar um lugar tão necessário e efetivo quanto um Tribunal de Justiça. Os Musqueam realizaram sua primeira exposição no MoA em 1986 e, desde então, sua presença neste museu tem sido expressiva e constante. Mas antes de abordarmos as relações e os trabalhos desenvolvidos entre os Musqueam e o MoA, acho necessário apontar para o contexto maior que, entre 1988 e 1992, mudaria para sempre as dinâmicas entre os museus canadenses e as First Nations.

\section{b) Os cenários museológicos como arenas políticas}

Em 1988, o Glenbow Museum da cidade de Calgary (província de Alberta, Canadá) inaugurou uma exposição intitulada "O Espírito Canta: Tradições Artísticas dos Povos Originários no Canadá" (The Spirit Sings: Artistic Traditions of Canada's First Peoples). A mostra contou com uma enorme publicidade pelo fato de ter sido inaugurada no contexto dos Jogos Olímpicos de Inverno, sediados dessa vez em Calgary. Nessa exposição apresentaram-se 650 peças de arte indígena vindas de diferentes museus de todo o mundo, correspondentes ao período dos primeiros contatos entre os aborígines do atual território canadense e os exploradores e comerciantes europeus. Muitos desses objetos quase não tinham sido exibidos anteriormente; eram desconhecidos não só dos indígenas, mas também dos curadores e dos pesquisadores (Phillips 2012b:48).

As reações à exposição "O Espírito Canta" foram díspares. Mas a maioria dos críticos afirmou que a mostra era insensível às condições presentes dos povos indígenas, chegando mesmo até a sugerir que apresentava as 
culturas nativas como vestígios pré-históricos. Entretanto, o maior problema desta exposição não foi tanto seu conteúdo, e sim seu sponsor: a companhia petroleira Shell Oil estava naquele momento em pleno conflito com o povo indígena Lubicon Lake Cree pela extração de petróleo nas terras reclamadas por estes (Herle 1994:39; Bolton 2004:2). Patrocinada pela Shell, "O Espírito Canta" era simultânea às triplas negociações entre o governo da província de Alberta, o Estado canadense e o governo dos Lubicon Lake Cree em relação à sua terra ancestral, aos títulos sobre essas terras e aos direitos já tratados anteriormente com os povos Lubicon. ${ }^{33}$ Assim, o controle sobre os recursos e sobre a representação cultural desencadeou o protesto. Os Lubicon organizaram então um boicote à exposição, chamando a atenção para o fato em escala nacional e internacional. ${ }^{34}$

Segundo Ruth Phillips (diretora do MoA entre 1997-2002), essa exposição foi o ponto de partida para a reforma museal pós-colonial que vinha se delineando nas últimas duas décadas. Citando a antropóloga Veena Das, afirma que constituiu o "evento crítico que estabeleceu novas modalidades de ação social" (Phillips 2012b:48-51; veja-se também Clapperton 2010:17-18) ${ }^{35}$

$\mathrm{Na}$ comunidade museológica canadense, a consequência imediata desses protestos foi a realização, durante os últimos dias da exposição em Ottawa, de uma conferência promovida pela Canadian Museums Association e pela Assembly of First Nations na Carleton University, em Ottawa. Intitulada "Preservando a nossa herança: uma conferência de trabalho entre os museus e as Primeiras Nações" (Preserving Our Heritage: A Working Conference for Museums and First Peoples), teve por propósito discutir as preocupações sobre a representação das culturas nativas e das respectivas histórias nas instituições museológicas canadenses. Na abertura, George Erasmus, uma das lideranças da Dene Nation, afirmou que

A exposição "O Espírito Canta" desencadeou uma controvérsia expressiva no Canadá. Colocou questões com as quais os museus tinham de lidar, e questões a que os Povos Nativos tinham de responder [...] Qual o papel que os Povos Nativos deviam desempenhar na apresentação do seu próprio passado, da sua própria história? [...] Quando a exposição veio para Ottawa, tivemos de perguntar à comunidade indígena como prosseguir. Podíamos continuar o boicote, mas precisávamos seguir em frente. Aquilo em que estamos a embarcar agora é o começo de um tipo de relação diferente entre dois aliados potencialmente fortes (George Erasmus apud Phillips 2012b:51; veja-se também Herle 1994:40).

O resultado daquela conferência - amplamente acompanhada pela imprensa nacional - foi a criação do "Grupo de Trabalho sobre Museus e 
Povos Originários" (Task Force on Museums and First Peoples).$^{36}$ A missão deste Task Force seria a de "desenvolver uma grelha ética e estratégias para que as nações aborígines representem a sua história e cultura em concordância com as instituições culturais" (Herle 1994:40-41; veja-se também Holm \& Pokotylo 1997).

Visando cumprir este objetivo, em 1992 foi publicado o relatório intitulado "Virando a Página: Forjando Novas Parcerias entre Museus e Povos Originários" (Turning the Page: Forging New Partnerships Between Museums and First Peoples). Nele se estabeleciam as mudanças necessárias para um novo modelo de parceria entre as First Nations e os museus do Canadá, devendo estes últimos desenvolver "relações e parcerias com First Nations relativamente à pesquisa, à preservação e à interpretação dos seus artefatos, cultura e história" (Neary 2005:2 apud Clapperton 2010:18). Embora distribuído primeiramente entre as organizações indígenas e os museus canadenses, esse novo modelo acabaria tendo alcance internacional (Phillips 2012b:51).

\section{c) Os Musqueam no MoA}

Como dissemos anteriormente, em 1986 os Musqueam montaram sua primeira exposição no MoA, através do trabalho colaborativo desenvolvido junto com o pessoal desse museu (veja-se Ames 1992). Intitulada "As mãos dos nossos ancestrais" (Hands of Our Ancestors), esta mostra sobre tecidos tradicionais incorporava também o trabalho de atuais tecedoras musqueam, explicando ao público que os desenhos das mantas eram e são elaborados para identificar a posição, a família e a comunidade de uma pessoa ("a história de quem nós somos é a história dentro das mantas"). ${ }^{37}$

Mais tarde (1988), e também em cocuradoria com o pessoal do MoA, os Musqueam montaram uma exposição de mais de 150 fotografias, intitulada "O orgulho de ser Musqueam" (Proud to be Musqueam). Exibidas cronologicamente, as fotografias mostravam as famílias extensas das reservas musqueam, acompanhadas por etiquetas que, redigidas em primeira pessoa, apresentavam e explicavam as histórias dessas famílias (Clifford 1997:129131; Phillips 2012a:73-74).

Na sólida base das relações estabelecidas através dessas mostras, e querendo levar à prática os princípios instituídos oficialmente no relatório do Task Force, entre 1994 e 1999 o MoA e os Musqueam apresentaram outras duas exposições, constituídas em sua maioria por objetos musqueam (Holm \& Pokotylo 1997:34). ${ }^{38}$ A primeira, "Escrito na terra" (Written in the Earth), foi exibida durante 1996 e 1997. Era uma mostra de 100 artefatos 
esculpidos em chifres, ossos, pedra e madeira, datados entre 508 e 4000 anos de antiguidade e provindos do território onde atualmente se encontra a UBC e o MoA; também havia cestaria, joalheria e tecidos contemporâneos, demonstrando a continuidade, a transformação e a vigência das tradições culturais musqueam (:35). Esta exposição foi concebida principalmente como uma resposta ao primeiro ministro do Canadá naquele momento, Pierre Trudeau, que tinha negado que houvesse algum sinal de que a terra aborígene pertencesse às First Nations. ${ }^{39} \mathrm{O}$ Musqueam Aaron Point se referia a "Escrito na terra" dizendo

Quem me dera ter visto estas esculturas e artefatos quando era mais jovem. Sentia que me faltava, no nível pessoal, alguma coisa em mim mesmo, no sentido de não saber de onde eu venho. Estes objetos prendem-nos a terra e conectam-nos com o passado. Dão um entendimento melhor da nossa vida. Têm uma ligação espiritual entre todos daqui da reserva. Percebe-se que viemos do mesmo povo (apud Holm \& Pokotylo 1997:41).

A segunda exposição foi "Debaixo do Delta" (From under the Delta). Esteve no MoA desde abril de 1997 até abril de 1999, e exibia talhas, figuras de pedra esculpidas e outros ornamentos com uma antiguidade e uma origem similares aos objetos da mostra anterior, colocados simultaneamente com imagens e narrativas dos Musqueam contemporâneos (Phillips 2012a:73, 195). Margaret Holm e David Pokotylo - arqueólogos que trabalharam nestas duas experiências - comentam que, enquanto o objetivo principal destas exposições tinha sido, para eles próprios, criar uma consciência pública sobre a beleza e a antiguidade da arte pré-histórica dessa região, os Musqueam estavam especialmente interessados em promover uma melhor compreensão do seu atual contexto cultural. Assim sendo, um primeiro passo desse trabalho colaborativo foi identificar aquilo que é considerado como sagrado ou sensível e, apesar de que só uns poucos musqueam conheciam aqueles materiais arqueológicos, todos eles manifestavam profundos laços culturais e espirituais com seus passados através desses objetos (Holm \& Pokotylo 1997:34).

Segundo Phillips (2012a), "Escrito na terra" e "Debaixo do Delta" envolveram as mais radicais e difíceis negociações sobre práticas museológicas e autoridade curatorial na história do MoA. Ambas foram inauguradas dois anos além do previsto, devido aos processos de negociações e decisões (Ames 1999:48; Holm \& Pokotylo 1997:40). ${ }^{40}$ A par desses processos, foram assinados tratados com os Musqueam muito detalhados sobre, por exemplo, como guardar e exibir os seus objetos, como trabalhar com as companhias 
de seguros, ou como devia ser o desenho das etiquetas e das vitrines de exposição (Phillips 2012a:73-74). Ainda sob a direção de Phillips, em 1997 também foi assinado um protocolo com os Musqueam estabelecendo os princípios que haveriam de orientar as futuras colaborações. ${ }^{41} \mathrm{O}$ ponto de partida desse protocolo foi o reconhecimento, por parte do MoA, de que a terra ocupada pelo museu é propriedade dos Musqueam.

Os desafios, os investimentos e as colaborações assumidas pelo MoA com os Musqueam encontravam suas raízes fundamentalmente neste reconhecimento territorial. Mas esse compromisso do museu também procurava mudar anteriores tendências: durante as décadas de 1970 e 1980, o mercado da arte tinha privilegiado os objetos provindos de outras First Nations da Costa Noroeste e, acompanhando esses interesses, o MoA tinha priorizado as exposições - tanto permanentes quanto temporárias - de objetos haida e kwakiutl (Phillips 2012a:74). Uma vez reconhecida oficialmente a ocupação territorial das terras musqueam pelo MoA, criaram-se a dívida e a obrigação correspondente que, a partir daquele momento, manteve a estreita relação de reciprocidade entre ambos. Esse reconhecimento também ganhou expressão territorial através da instalação, em 1999, das esculturas monumentais musqueam (denominadas houseposts, "postes familiares") no espaço ao ar livre do museu, tornando explícita a propriedade musqueam daquele território, e sendo eles os que, através dos houseposts, dão as boas-vindas aos visitantes do MoA.

\section{Acerca dos processos de indigenização dos museus: semelhanças e diferenças}

Tanto o Museu Magüta quanto as mostras musqueam do MoA são resultado de processos políticos ativados pelos próprios indígenas. Nesses espaços museais, Ticunas e Musqueams empenham-se em tornar esses processos tão visíveis quanto os objetos dos seus acervos.

O Museu Magüta, concebido pelas lideranças do CGTT como mais uma estratégia para acompanhar suas reivindicações, foi - mesmo com algumas ajudas externas - projetado, criado e dirigido por indígenas, e mantido até hoje graças ao seu esforço permanente. Suas instalações foram construídas como uma prolongação da sede do Centro Magüta, sendo este um espaço de decisões políticas com uma intensa trajetória de encontros e discussões entre capitães, pesquisadores e diversas instituições; um espaço onde, aliás, foram organizadas todas as atividades de demarcação fundiária, e que se transformaria na sede atual do CGTT. O Centro " [...] teve um papel essencial 
de locus de articulação e resistência dos Ticuna em face da pressão governamental para redução das suas terras" (Pacheco de Oliveira 1999:250; grifo no original). Segundo este autor, seria a estreita relação do Museu Magüta com o projeto político do CGTT que garantiria a singularidade deste museu indígena, podendo ser definido como tal a partir "das formas e funções que tal instituição assume dentro das estratégias políticas delineadas por uma coletividade ao longo de sua história" (Pacheco de Oliveira 2012a:217). As motivações que criaram o Magüta e que o mantêm aberto excedem qualquer experiência visual de cultura material: os objetos ticuna são acervos comunitários que visibilizam uma luta histórica, cultural e política, reivindicando seu passado, sua identidade e seu direito ao território. O vínculo que nessa luta articula cultura e política é apontado enfaticamente por Pacheco de Oliveira, quando afirma

A associação entre estes dois objetivos (território étnico e tradição cultural) foi estabelecida de maneira orgânica e emblemática desde a criação do CGTT através de atos simbólicos [...] Ao tentar fazer coincidir as assembleias com processos rituais, ao instituir a língua ticuna como meio oficial de comunicação neste contexto político crucial, ao chamar de "Magüta" o veículo de informação escrita da entidade, ao reproduzir na capa de cada jornal o episódio central de sua criação - por todos estes atos simbólicos, tradição e política foram tecidas como uma peça única, como algo indissociável (Pacheco de Oliveira 2012a:218; grifo meu).

O Magüta nasceu como produto dessa indissociabilidade. De fato, não por acaso tem sido alvo de diversas ameaças ao longo do tempo. Esses violentos incidentes demonstram, de forma clara e contundente, que o uso do museu como mais um instrumento de luta era algo evidente não só para os indígenas, mas também para seringueiros, madeireiros e políticos. Atacar e/ ou destruir este museu era silenciar, prejudicar e/ou desestruturar os Ticuna de forma direta. Todos esses invasores pareceram reconhecer que o Magüta era um instrutor poderoso e de grande alcance: podia ensinar sobre o passado dessas terras em disputa, demonstrando antiguidades e continuidades e, dessa forma, modificar os critérios para pensar a propriedade da terra no presente. O Magüta é, ele próprio, um órgão e um processo político.

Quanto ao MoA de Vancouver, está localizado em território musqueam, mas esta instituição não é indígena. Apelando para a obrigação criada pela cessão do uso desse território - isto é, fazendo valer os seus direitos é que o povo Musqueam coloca as suas premissas e os seus interesses na elaboração das mostras; entretanto, eles se inserem nas negociações 
envolvidas nas práticas colaborativas exercidas pelo MoA - que, por sua vez, considera os seus próprios interesses e premissas. Talvez seja válido perguntarmo-nos como poderiam ter se organizado essas mostras se tivessem sido norteadas unicamente por critérios musqueam. No entanto, foram objeto de discussões e acordos entre as duas partes, e, considerando o particular vínculo de reciprocidade estabelecido entre ambos os parceiros, parece-nos que o MoA, neste caso, adquiriria então uma dimensão fundamentalmente compensatória: os direitos musqueam de avaliar todas as práticas (em torno das peças, das mensagens das exposições, da divulgação de conteúdos etc.) que visam, de alguma forma, ressarcir tanto políticas governamentais prévias ao uso do território musqueam pelo museu quanto a condição de usufruto desse território no presente.

O compromisso estabelecido com os Musqueam é diferente dos vínculos que o MoA mantém com outras First Nations, e o aparente privilégio com os primeiros não foi sem consequências para os outros. Johnathan Clapperton, intelectual da Stó:lō Nation, afirma que "Quando o MoA acentua uma das First Nations, as outras sentem-se inevitavelmente diminuídas ou abandonadas" (Clapperton 2010:28). Aparentemente, este parece ter sido o caso. A produção das exposições acima mencionadas excluiu First Nations que se sentiram, precisamente por causa disto, "duplamente colonizadas: uma primeira vez pelo MoA, e uma segunda vez por esse povo indígena particular" (:28). Apesar de não podermos aprofundar aqui cada um dos vínculos entre este museu e as distintas First Nations representadas nos seus acervos, tais vínculos sugerem uma diversidade de relacionamentos que levantam questões interessantes aos princípios da política colaborativa levada à prática por este museu.

Estabelecidas estas diferenças preliminares entre os tipos de agência indígena no Magüta e no MoA, como poderíamos identificar e/ou falar de processos de indigenização nessas instituições? Segundo Phillips (2012d), o termo indigenização acarretaria dois sentidos diferentes. O primeiro seria literal, significando a incorporação, por parte da museologia dominante, dos conceitos, dos protocolos e dos processos originados nas sociedades indígenas, obtidos através de consensos entre estas e os museus, em condições igualitárias de negociação. Conforme esta autora, o resultado dessa indigenização poderia ser entendido como uma classe de hibridização, conduzindo para caminhos mais dialógicos na representação pública de tradições culturais particulares (:10).

O segundo sentido de indigenização estaria se referindo ao "característico modelo canadense de negociação pluralista", no qual as negociações privilegiam "uma capacidade pragmática para o acordo e, por outro lado, uma 
aproximação que reconhece, caso por caso, a singularidade de comunidades particulares e suas necessidades" (:10). Explicando que os casos museológicos por ela estudados fizeram parte de processos muito similares àqueles geralmente desenvolvidos na sociedade canadense, destaca como as políticas desse país se caracterizam pela cultura da negociação e pela habilidade "para tolerar anomalias e ambiguidades" (:10). Por outro lado, a autora argumenta que ambos os sentidos de indigenização derivariam do status indígena como o "Outro significativo" do Canadá, posição estrutural compartilhada por todos aqueles povos que contestam histórias nacionais e coloniais. ${ }^{42}$

Parece-me que a autora traz à tona os discursos do poder para apoiar as suas definições. A primeira delas reduz o significado da indigenização à incorporação, nos museus convencionais, de noções e práticas de origem indígena, processo que, por sua vez, poderia ser compreendido como uma classe de hibridização. Acho que este último termo é poderosamente esclarecedor porque destrói, ele próprio, o argumento da autora, quase nos poupando essa tarefa. O Museu Magüta e as mostras musqueam articulam estratégias de luta fundiária, habilitam espaços de políticas performativas, mobilizam memórias, fazem seleções historiográficas que desafiam as histórias coloniais, expõem processos de formação de identidades, combatem preconceitos. Estas ações políticas - concretas e situacionais, ativadas pelos próprios indígenas - não poderiam nunca ser subsumidas a uma forma de hibridismo que simplesmente conjugaria "museus dominantes + conteúdos indígenas". Longe disso, considero que a indigenização dos museus consiste nos processos ativados pela agência indígena nas instituições museológicas, colocando o reconhecimento do seu direito soberano à autorrepresentação, à propriedade e à administração dos seus próprios saberes e tradições, exercendo, portanto, seu direito à identidade, a terra, ao passado, à história e à memória.

No entendimento da ideia de indigenização, a minha definição aponta para seu componente etnográfico: ela descreve processos que estão fora daqueles da descolonização, na medida em que reclamam afirmativamente uma identidade cultural que não tem mais "o colonial" como referência. A questão colonial é parte do cenário, mas já não é o centro, agora ocupado pela afirmação da identidade; trata-se, portanto, de um processo cívico, literalmente pós-colonial. Por outro lado, nesta perspectiva, não se trata, em primeiro lugar, "da incorporação, pela museologia dominante, dos conceitos, dos protocolos e dos processos originados nas sociedades indígenas", e sim da conquista da cena museológica pela agência indígena: são os índios que estão abordando os museus, e não o contrário. De fato, todas as modificações implementadas no cenário museológico canadense têm sido desenvolvidas 
como uma resposta às demandas e às necessidades dos indígenas, não dos museus. Isto remete às "condições igualitárias de negociação" mencionadas por Phillips. Sem dúvida, a autora reconhece a trajetória museal canadense de discussões e tratados (especialmente no que se refere às recomendações do Task Force, comentadas previamente). No entanto, e como desenvolvi em outro trabalho (Roca 2015), as práticas colaborativas nem sempre implicam parcerias em termos de igualdade, e nas estruturas dialógicas sempre há quem possa falar mais alto.

Quanto ao segundo sentido de indigenização apontado por Phillips, ele é, a meu ver, profundamente paternalista e colonial, colocando a sociedade canadense como modelo negociador que "reconhece as singularidades de comunidades particulares e suas necessidades" e "tolera as anomalias e as ambiguidades" das outras partes (não canadenses?) envolvidas nessas negociações. No meu entender, trata-se de uma reprodução da versão nacionalista da história do Canadá construída pelos colonos - uma história quase sem conflitos e baseada na negociação. Ainda que pudesse existir algo identificável como "modelo da política negociadora canadense", é importante termos em mente que a afirmação de todas essas bondades tem lugar em um país onde o Indian Act mantém ainda vigentes seus princípios básicos de assimilação e controle, onde a última escola residencial indígena deixou de funcionar em 1996, e onde diariamente há manifestações indígenas de repúdio contra os oleodutos que, daqui a pouco, atravessarão grande parte das suas terras. ${ }^{43}$

Por último, é necessário destacar que a autora faz referência a museus convencionais, já existentes, que teriam sido "hibridizados" por ideias e práticas que lhes são alheias. Diferentemente, ao falar em indigenização dos museus, não estou pensando em casos específicos, e sim na instituição museológica como um todo, a partir de uma perspectiva histórica. Neste sentido, por exemplo, o Magüta é tanto um museu indígena quanto mais um caso de "indigenização" do espaço museológico, pelo fato de os Ticuna terem se apropriado desta instituição — tradicionalmente branca e ocidental, alheia a eles - como conceito, como prática e como performance política.

Considerando estas colocações, quero finalizar apontando para três elementos que, parece-me, são complementares entre si. O primeiro é que os processos de indigenização dos museus - diversos como eles são, necessariamente - providenciam narrativas genealógicas alternativas sobre os museus e conectam-nos diretamente com lutas indígenas que são fluidas, emergentes e extremamente localizadas, mas que possuem um denominador comum: o controle indígena sobre seus recursos, estreitamente vinculado ao controle sobre sua representação cultural. 
Sem sombra de dúvida, as práticas que têm constituído o Museu Magüta e o lugar dos Musqueam nas mostras do MoA estão indigenizadas porque têm suas origens e razão de ser no ativismo indígena; entretanto, acho necessário estabelecer algumas diferenças. Quando comparamos os processos de autorrepresentação viabilizados nas mostras musqueam com a total soberania desses processos no caso dos Ticuna - sendo o Museu Magüta, ele próprio, um órgão político implementado como parte das reivindicações fundiárias - a expressão indigenização dos museus adquire significados e alcances bastante diferentes, evidenciando-se sua extrema complexidade. Trata-se, portanto, de identificar as particularidades próprias a cada processo, observando e analisando os graus de autonomia na apropriação de projetos, nomes, objetos e símbolos, assim como no traçado de tradicionalismos adaptativos e/ou estratégicos e na administração política de todas essas seleções, sendo necessário, ao mesmo tempo, conhecer e examinar os diferentes sentidos de "comunidade imaginada" criados nessas dinâmicas (Anderson 1993 apud Clifford 2013).

Certamente, a indigenização dos museus corre a par da descolonização museológica, ainda em andamento. Longe de se constituir como um exercício político uniforme, essa indigenização é tão diversa quanto os povos, as histórias, os relacionamentos e os contextos (sociais, econômicos, políticos) que dão vida a esses espaços e instâncias museológicas. No entanto, vale a pena destacar que a gravidade das situações de dominação, exploração e extração de recursos parece colocar, às vezes, certas estratégias museais com especial clareza (lembremos, por exemplo, que o Museu Magüta foi um desdobramento direto das atividades do CGTT na luta fundiária; por sua vez, a exposição musqueam "Escrito na terra" foi uma resposta imediata ao primeiro ministro Trudeau, quando este negou, publicamente, o direito dos Musqueam à sua propriedade).

Em segundo lugar, é necessário considerar que enquanto estes exemplos tornam evidente que a cultura é uma dimensão política que aparece na arena dos museus, estas lutas demonstram que o conhecimento indígena pertence aos seus criadores e que, mesmo podendo ser cooptado e incorporado em formas coletivizadas de processos alternativos, estes já não se restringem às opções museológicas tradicionais (isto é, o museu como produtor da representação do Estado-nação, ou dependente da economia do mercado). Pelo contrário, para os povos indígenas, tanto o Estado-nação como o mercado seriam vistos como fontes de opressão, e o Magüta (primeiro museu indígena do Brasil) e as mostras musqueam no MoA (um museu universitário, pioneiro em práticas colaborativas) representam outras entidades políticas. 
Em terceiro lugar, as formas de conhecimento que se procura produzir estão orientadas para os seus utilizadores imediatos, em clara oposição às tradições epistêmicas ocidentais (o conhecimento como algo universal e per se). A preocupação de Ticunas e Musqueams em torno da instituição museológica parece ter sido encontrar a maneira pela qual, em primeiro lugar, seus próprios povos aprendessem sobre suas histórias e culturas, e sentissem orgulho delas. Seus desafios epistemológicos são, ao mesmo tempo, apostas políticas. Diferentemente das trajetórias geralmente envolvidas na vida social dos objetos exibidos nos museus - entre povos, lugares, pessoas, instituições etc., no sentido de "viagens" (Clifford 1997) - seus acervos desenvolvem trajetórias locais e concepções autocentradas (e intencionais) de "ser Magüta" e "ser Musqueam". Eles falam de si próprios, em primeiro lugar para si próprios, e em função de um passado construído por eles, projetando-se para o futuro.

Nas mãos dos indígenas, o uso dos seus acervos põe em funcionamento o potencial crítico dessas coleções, contestando as histórias e as historiografias coloniais, indigenizando o conhecimento e realizando demarcações de natureza política. Essas formas de produção de conhecimento implicam acordos ad-hoc que definem quais são, circunstancialmente, as maneiras apropriadas de lidar com suas diferentes demandas. Consequentemente, incorporam protocolos de comportamento e compromissos éticos na definição das condições da sua produção, inscrevendo objetivos conflituosos nos processos de formação desses conhecimentos, e sugerindo realinhamentos pós-coloniais mediados pela agência indígena através das instituições museológicas. Estas últimas resultam eficazes instrumentos de afirmação política, propiciando, aliás, o exercício da reflexividade e do trabalho crítico de reconceituação de acervos e heranças coloniais, abrindo-se para uma pluralidade de novos usos sociais - que, por sua vez, articulam as políticas sociais com a natureza do conhecimento, gerando ao mesmo tempo projetos políticos para a sociedade.

Recebido em 14 de julho de 2014

Aprovado em 25 de fevereiro de 2015

Andrea Roca é pesquisadora do LACED/MN/UFRJ. E-mail: <andreacmroca@ gmail.com> 


\section{Notas}

* Este artigo tem suas origens no paper "Museum Mediations: Knowledges, Experiences, Memories, Technologies, the State and Civil Society", apresentado junto com Nuno Porto (MoA, UBC) no 111th Annual Meeting of the American Anthropological Association, San Francisco (2012). Agradeço à Fundação Carlos Chagas Filho de Amparo à Pesquisa do Estado do Rio de Janeiro (Faperj) pela bolsa de pós-doutorado que possibilitou o desenvolvimento desta pesquisa. Todas as traduções do inglês para o português são minhas.

${ }^{1} \mathrm{Na}$ elaboração desta parte tenho me baseado principalmente em alguns dos trabalhos de João Pacheco de Oliveira (1996, 1999, 2002, 2012a; também 1988 e 1991, em parceria com Antonio Carlos de Souza Lima). O autor vem atuando junto aos Ticuna desde a década de 1970, elaborando mais tarde sua dissertação de mestrado (1977) e sua tese de doutoramento (1989), ambas focadas na sua organização política. Foi o primeiro presidente do Centro Magüta, e o impulsionador de todos os projetos entre os Ticuna e o Museu Nacional.

2 Veja-se Magüta 2014, e, no site do ISA, http://pib.socioambiental.org/pt/povo/ ticuna. Acesso em fev.2014.

${ }^{3}$ O SPI tinha estado presente desde 1917, mas só de maneira formal, limitando-se à elaboração de relatórios e sem interferir no domínio dos seringalistas (ISA 2014). Naquele então, só os vinculados ao SPI se chamavam de índios, enquanto a maioria das comunidades - dependente dos "patrões" - identificava-se como "cabocla". Junto com esta agência do Estado, a partir de 1910 também estiveram presentes na região capuchinhos italianos e, durante a década de 1960, missionários batistas norte-americanos.

${ }^{4}$ Entre eles, Pacheco de Oliveira.

${ }^{5}$ Veja-se "O que é o CGTT" em CEDI (1991:241).

${ }^{6}$ Até 1992, a Diretoria do Centro Magüta foi constituída por não índios, tendo como presidente Pacheco de Oliveira. A partir das eleições daquele ano, passou a ter uma Diretoria mista. O capitão geral Pedro Inácio Pinheiro ameaçou retirar a sua candidatura se Pacheco de Oliveira não fosse incluído nela como vice-presidente, justificando este pedido em função da "necessidade de assinatura de muitos papéis". Veja-se Pacheco de Oliveira (2012a:214); também Bruno (2002:12 apud Paladino 2006:83). A partir de 1996, a Diretoria seria composta unicamente por indígenas.

${ }^{7}$ Veja-se http://pib.socioambiental.org/pt/povo/ticuna/1344. A Funai-Tabatinga tinha recebido 80 vagas de professores para as escolas indígenas (Pacheco de Oliveira 2012a:208). Referindo-se à ação do Centro Magüta no campo educativo, Mariana Paladino afirma que "existia a necessidade de formar lideranças para impulsionar o 
seu processo de união e organização, e para capacitá-las no seu papel de intermediários entre os indígenas e os órgãos de governo e outras agências" (Paladino 2006:85).

${ }^{8} \mathrm{O}$ "patrão" era Oscar Castelo Branco. A respeito deste massacre, vejam-se Pacheco de Oliveira e Souza Lima 1988, 1991; CEDI 1991:243-248; Fernandes 2011.

${ }^{9}$ Uma vez na prisão, foram soltos em menos de 30 dias, esperando o julgamento do processo em liberdade. Finalmente, em 7 de junho de 2001 - 13 anos depois do massacre - os assassinos foram condenados de 20 a 25 anos de prisão. Veja-se http:// pib.socioambiental.org/es/noticias?id=3138. Acesso em 25/03/2014.

${ }^{10}$ Veja-se a notícia sobre os preparativos em "Um museu para fortalecer identidade Ticuna" (CEDI 1991:255-256), apresentando-o "como parte das atividades do Centro Magüta".

${ }^{11}$ Comentando o processo de definição dos significados das peças ticuna do Museu Goeldi (coletadas por Curt Nimuendajú em 1941/42), Priscila Faulhaber (2005) oferece uma interessante análise da dinâmica das diferentes interpretações sobre os objetos entre os Ticuna que moram nas cidades, por um lado, e aqueles que vivem nas aldeias, por outro.

${ }^{12}$ Outras fontes colocam o dia 6 de dezembro de 1991 como a data exata da inauguração (vejam-se Benzi Grupioni 1994:269; Bessa Freire 2003:224). Este último autor inclusive afirma que esse evento devia ter acontecido antes, mas que, no dia da suposta inauguração, o prefeito da cidade de Benjamin Constant convocou uma grande quantidade de público na frente do museu, manifestando-se hostilmente contra a demarcação das terras indígenas. A repercussão desses incidentes na imprensa e em algumas instituições da região fez com que o museu conseguisse abrir suas portas três semanas depois (Bessa Freire 2003:221). Entretanto, o Instituto Brasileiro de Museus (Ibram) nos informa que o Museu Magüta "só veio a ser oficialmente inaugurado em 1994" (Ibram 2010).

${ }^{13}$ Segundo Bessa Freire (2003:223), nos primeiros cinco anos passaram por lá mais de 6.000 pessoas.

${ }^{14}$ De acordo com Pacheco de Oliveira (2012a:214-215), a necessidade de marcar distância com o CGTT levou a OGPTB a uma crescente despolitização: sem querer estabelecer vínculos - nem no passado, nem no presente - com aquele Conselho, os materiais desenvolvidos pela OGTPB passaram a focar nas tradições culturais e na mitologia ticuna, mas sem nenhuma referência às mobilizações políticas pela demarcação de terras, nem aos protagonistas dessas lutas.

${ }^{15}$ Explicando o processo que levou ao fechamento do Centro Magüta, Pacheco de Oliveira atesta que, além de ter se criado nele um patrimônio "invejável para uma pequena ONG situada no interior da Amazônia [...] também [o Centro] criou um quadro fixo e profissional de colaboradores (agora transformados em funcionários), com interesses corporativos e práticas clientelistas, envolvendo inclusive assessores. 
A partir de 1994 tal rede de funcionários, eficiente na caça de recursos financeiros e na tentativa de monopolizar a função política de mediação externa, pretendia tornar-se inteiramente imune à autoridade dos capitães (que são os únicos que possuem legitimidade para os Ticuna e podem, portanto, atuar como seus representantes políticos). As assembleias de capitães recomendaram a dissolução da entidade e sua entrega à organização indígena CGTT [...] a qual reabriu o museu, instituiu um sistema de trabalho não remunerado (voluntário e rotativo) e preparou projetos sobre desenvolvimento sustentável para execução direta nas aldeias" (Pacheco de Oliveira 1999:251; ver também 2012a:216).

${ }^{16}$ No contexto de um seminário levado a cabo no Museu Nacional em junho de 1999, Nino Fernandes, representando o CGTT, expressava: “[...] Estamos conseguindo tomar conta do Museu, os próprios indígenas é que estão trabalhando, cuidando das peças, sem orientação de ninguém, de artista plástico, museólogo etc. Não temos nenhum tipo de ajuda, as próprias lideranças às vezes é que têm que varrer e capinar o terreno do Museu [...]" (Fernandes 1999).

${ }^{17}$ Maria Helena Cardoso de Oliveira e Alessandra Marques (apud Bessa Freire 2003).

${ }^{18}$ A informação desta parte está baseada principalmente em Shelton e Mayer (2009), e no website do MoA, http://www.moa.ubc.ca/.

${ }^{19}$ Diferentemente do resto do Canadá, 95\% do território da província da British Columbia são "terras não cedidas", isto é, não foram assinados tratados ou outro tipo de contratos - coloniais, federais ou provinciais - entre os indígenas e a Inglaterra ou o Canadá. O conceito de "títulos indígenas sobre as terras" tem sido rejeitado pelos sucessivos governos provinciais. Não obstante, a partir das décadas de 1980 e 1990, os indígenas têm se organizado e há muitos tratados modernos em curso: em março de 2013, eram 60 as First Nations de BC negociando com os governos nacional e provincial (veja-se First Peoples 2014:48-54). Os Musqueam entraram em negociações em 1994 (Musqueam People 2011:43).

${ }^{20}$ Em 1975, provinda de Walter e Marianne Koerner. Atualmente, o acervo dos povos indígenas da Costa Noroeste conforma só 18\% das coleções deste museu; entretanto, a visibilidade expositiva destas coleções (ocupando o espaço mais importante do MoA, seu magnífico Grand Hall) consegue criar a sensação de se tratar de um museu orientado principalmente para esses povos, quando, na realidade, a maior parte das suas coleções é de origem asiática (40\%).

21 "Primeiras Nações": nome dados aos povos indígenas do Canadá segundo a Constituição canadense.

${ }^{22}$ Veja-se http://www.rrncommunity.org/. Disponibilizando estes materiais para todo tipo de público, a rede também oferece a possibilidade de acrescentar novas pesquisas sobre as peças desses inventários. Assim, esta tecnologia de mediação e informação tem acrescentado camadas de significados, de pensamentos e de formas 
de operar nas transformações em curso sobre a agência do museu, na medida em que permite uma deslocalização relativa da produção do conhecimento e distribui modalidades elocucionárias sobre o conhecimento cultural.

${ }^{23}$ A informação desta parte está baseada principalmente em Musqueam People (1984, 2012, 2014) e First Peoples (2014).

${ }^{24}$ Veja-se Musqueam People (2011:49; 2012). Com 40\% de jovens, calculam que, para 2030, a população estará na faixa das 2.300 pessoas.

${ }^{25}$ North Vancouver, South Vancouver, Burrard Inlet, New Westminster, Burnaby e Richmond. Nesta última localidade encontra-se o Aeroporto Internacional de Vancouver; nele, somos recebidos por várias esculturas musqueam, que anunciam termos chegado ao seu território.

${ }^{26}$ Sob o comando dos capitães Narváez, Vancouver e Galiano (Musqueam People 2011:42).

${ }^{27} \mathrm{O}$ Bando era uma comunidade de First Nations, cujos membros eram definidos pelo governo; esses Bandos podiam escolher seus Conselhos e um chefe. A respeito do Indian Act, é importante destacar que, apesar das mudanças negociadas e aplicadas até hoje sobre ele, ainda conserva seus dois princípios básicos: assimilação e controle (First Peoples 2014:44).

28 "[...] to kill the Indian in the child". Duncan Campbell Scott (1920), chefe dos Indian Affairs - Government of Canada durante o período 1913-1932 (apud First Peoples 2014:56).

${ }^{29}$ Houve um total de 140 escolas residenciais espalhadas por todo o Canadá. Só deixaram de funcionar em 1996 (veja-se First Peoples 2014:56-62). Em 2008, o atual primeiro ministro Stephen Harper pediu públicas desculpas aos indígenas em nome do governo pelas atrocidades cometidas contra eles nestas escolas, estabelecendo a "Comissão de Verdade e Reconciliação" (Truth and Reconciliation Comission) (First Peoples 2014:79-85)

${ }^{30} \mathrm{O}$ salmão se reproduz massivamente a cada quatro anos, gerando portanto os melhores anos de pesca. Esse ciclo dominante costumava ter, nas décadas de 1910 e 1920, uma média de 20 milhões de salmões; na década de 1980, esta média tinha passado para apenas 2 milhões.

31 "Somos um povo orgulhoso e unificado, que se autogoverna [...] e constrói sua comunidade sobre valores tradicionais e históricos". Veja-se http://www.musqueam. bc.ca/sites/default/files/musqueam_declaration.pdf. Acesso em: 30/03/2014.

${ }^{32}$ Em 2003, o governo vendeu a setores privados terrenos que faziam parte dos territórios ancestrais dos Musqueam. Estes entraram na Justiça e, em 2008, não só conseguiram a recuperação de espaços equivalentes àqueles que tinham sido 
vendidos, como também uma compensação, por parte do governo, de 20 milhões de dólares (Veja-se http://ubcinsiders.ca/2011/08/courts-uphold-transfer-of-university-golf-course-other-lands-to-musqueam/. Acesso em: 30/03/2014).

${ }^{33} \mathrm{Na}$ década anterior, os Lubicon já tinham sido forçados a abandonar seus territórios ancestrais quando a Shell começou a perfurá-los, sofrendo uma drástica deterioração no seu modo de vida (Phillips 2012b:49).

${ }^{34}$ Não obstante, "O Espírito Canta" cumpriu a agenda programada desde o começo: de 15/01 até 01/05/1988 no Glenbow Museum, e de 01/07 até 06/11/1988 no Canadian Museum of Civilization, em Ottawa.

${ }^{35}$ Segundo esta autora, a virada museológica produzida pela exposição "O Espírito Canta" teria tido lugar de qualquer maneira, com ou sem ela, dadas as condições do ativismo indígena em torno das lutas pela terra e os reclamos por justiça social. Como parte desses processos, alguns povos indígenas - entre eles, os Musqueam - já tinham começado a intervir em alguns aspectos das práticas museológicas; veja-se Phillips (2012b:53-55).

${ }^{36}$ Para uma listagem completa dos membros da Task Force, vejam-se Bolton (2004) e Herle (1994:41).

${ }^{37}$ Deborah Sparrow (tecedora musqueam), no vídeo "Musqueam Trought the Time" (http://www.musqueam.bc.ca/). Veja-se também Musqueam Weavers (MoA; sem data). Os conteúdos dessa exposição foram desenvolvidos na obra de Elizabeth L. Johnson e Kathryn Bernick (1986).

${ }^{38}$ Embora houvesse objetos de territórios tradicionais de outras sete comunidades independentes de First Nations, que também trabalharam conjuntamente com o MoA no desenvolvimento da exposição (Holm \& Pokotylo 1997:35). Chama a atenção que a bibliografia aqui consultada - elaborada por pessoas que trabalharam de forma direta nesses processos - não mencione de que nações se trata (sublinhando-se, a meu ver, a hegemonia dos Musqueam sobre o MoA, que será desenvolvida mais à frente).

${ }^{39}$ Segundo Deborah Sparrow, "Durante uma cimeira entre líderes aborígines e Pierre Trudeau, foi-lhe dito que a terra pertencia aos povos nativos; que o Criador nos deu a terra para nós cuidarmos dela. Trudeau questionou: "Por que seria de vocês? Não vejo nenhum sinal de que a terra lhes pertença. Onde está escrito que lhes pertence?". Eu pensei para mim própria: está escrito na terra. As provas de que temos vivido nesta terra estão por todo o lado. Em qualquer lugar que escavamos, desenterramos mensagens do passado... Eu penso nestes objetos como parte de mim, como parte daquilo que somos. Um museu não é só uma instituição: é um lar para estes objetos e para os povos que eles representam" (apud Phillips 2012a:74; este texto fazia parte dos painéis desta exposição).

${ }^{40}$ Ames admitia que, apesar de o pessoal do MoA ter estado comprometido com os princípios colaborativos desde o começo, não foi fácil levá-los à prática: muitas 
vezes era complicado, para os profissionais dos museus, compreender os alcances das negociações. Cita o exemplo de um designer do MoA: "[...] no começo, ele se perguntava que direito tinham [os indígenas] para desafiar suas ideias do desenho da exposição, dado que ele era um designer reconhecido. Disse-me que, uma vez ele tendo assumido que os povos indígenas possuem suas próprias histórias, ele percebeu que eram eles os que tinham todo o direito de dizer como as coleções deviam ser montadas e interpretadas" (Ames 1999:46).

${ }^{41} \mathrm{O}$ documento foi produto de muitos meses de discussões e negociações prévias entre Michael Ames e os Musqueam Leona Sparrow e Howard Grant - representantes escolhidos pelos Musqueam para trabalhar em "Escrito na terra" e "Debaixo do Delta" (Phillips 2012a:75).

${ }^{42}$ A pergunta aqui seria: "significativo" para quem?

${ }^{43}$ De fato, enquanto estava terminando este artigo, em 17 de junho de 2014 foi aprovada a realização do oleoduto, de quase 1.200 kilômetros, que unirá as cidades de Burderheim (província de Alberta) com Kitimat (British Columbia; veja-se http:// www.cbc.ca/news/canada/calgary/northern-gateway-pipeline-approval-alberta-reacts-1.2678818. Acesso em 30/06/2014). Orçamentado em 6,5 bilhões de dólares, a justificativa de sua realização é, mais uma vez, "a criação de postos de trabalho" para a sociedade canadense.

\section{Referências bibliográficas}

ABA - Associação Brasileira de Antropologia. 2009. "Nota sobre a ameaça iminente de fechamento do Museu Maguta" (http:// www.abant.org.br/?code=2.31. Acesso em 15/03/2014)

AMES, Michael.1992. Cannibal tours and glass boxes: the anthropology of museums. Vancouver: University of British Columbia Press.

1999. "How to decorate a house: the re-negotiation of cultural representations at the University of British Columbia Museum of Anthropology". Museum Anthropology, 22(3):41-51, American Anthropological Association.
ANDERSON, Benedict. 1993. Comunidades imaginadas: reflexiones sobre el origen y la difusión del nacionalismo. México: Fondo de Cultura Económica. BENZI GRUPIONI, Luíz Donisete (org.). 1994. Índios no Brasil. Brasília: MEC BESSA FREIRE, José Ribamar. 2003. "A descoberta do Museu pelos índios da Amazônia". In: Regina Abreu; Mário Chagas (orgs.), Memória e patrimônio: ensaios contemporâneos. Rio de Janeiro: DP\&A. pp. 219-254.

BOLTON, Stephanie. 2004. An analysis of the task force on museums and first peoples: the changing representation of aboriginal histories in museums. 
Dissertação de Mestrado em História da Arte. Concordia University, Montreal, Canada.

BRUNO, Paulo R. 2002. Estudos sobre a educação escolar entre os Ticuna do Alto Solimões. Dissertação de Mestrado, PPGE/UFF.

CARDOSO DE OLIVEIRA, Roberto. 1964. O índio e o mundo dos brancos. São Paulo: Livraria Pioneira.

CEDI - Centro Ecumênico de Documentação e Informação. 1991. Povos indígenas no Brasil, 1987-1990. São Paulo: CEDI. Série Aconteceu Especial, 18.

CLAPPERTON, Jonathan Alex. 2010. "Contested spaces, shared places: The Museum of Anthropology at UBC, aboriginal peoples, and postcolonial Criticism". B.C. Studies, 165:7-30.

CLIFFORD, James. 1997. Routes. Travel and translation in the late twentieth century. Cambridge: Harvard University Press.

- 2013. Returns. Becoming indigenous in the twenty-first Century. Cambridge: Harvard University Press.

FAULHABER, Priscila. 2005. "O etnógrafo e seus 'outros': informantes ou detentores de conhecimento especializado?". Estudos Históricos, 36:111-129.

FERNANDES, Nino. 1999. Texto lido no Seminário "Bases para uma nova política indigenista 1", Mesa "Movimentos indígenas, ONG's e cooperação internacional: as sociedades indígenas como parceiras e gestoras de programas de desenvolvimento". Museu Nacional, Junho 1999. Disponível em http://laced.etc.br/site/atividades/seminarios/ seminario-bases/mesa-1/Acesso em 04/02/2014.

· 2011. "Museu Maguta: resistência dos Ticuna contra o preconceito" In: Vozes da Amazônia, 15/09/2011. http://vozesdaamazonia.blogspot.ca/2011/09/ museu-maguta-resistencia-dos-tikuna. html. Acesso em 04/02/2014.
FIRST PEOPLES. 2014. First peoples: a guide for newcomers. City of Vancouver, Province of British Columbia. Mimeo.

HERLE, Anita. 1994. "Museums and first peoples in Canada". Journal of Museum Ethnography, 6:39-67.

HOLM, Margaret; POKOTYLO, David. 1997. "From policy to practice: a case study in collaborative exhibits with first nations". Journal Canadien d'Archéologie, 21:33-43.

IBRAM - Instituto Brasileiro de Museus. 2010. "IBRAM e UFRJ assinam termo de cooperação para museu dos Ticuna" In: http://www.museus.gov.br/ibram-e-ufrj-assinam-termo-de-cooperacao-para-museu-dos-ticuna/. Acesso em Março 2014. - 2011a. Museus em Números (vol.1). Brasília: IBRAM.

. 2011b. "Projeto do IBRAM leva qualificação a museu da etnia Ticuna". In: e-museus. Boletim Eletrônico no. 371. Ano VIII, 22 a 29 de setembro de 2011; http:// boletim.museus.gov.br/?p=3336\#3358. Acesso em 04/04/2014.

ÍNDIOS TICUNA. 1985. Torü Dü̈'Ügü (Nosso Povo). Rio de Janeiro: Museu Nacional/ UFRJ - SEC/MEC/SEPS/FNDE.

ISA - Instituto Sócio-Ambiental. 2014. Povos Indígenas no Brasil. Instituto Socioambiental (http://pib.socioambiental. org/pt/povo/ticuna/print). Acesso em 21/03/2014.

JOHNSON, Elizabeth L.; BERNICK, Kathryn. 1986. Hands of our ancestors: the revival of salish weaving at Musqueam. Vancouver: UBC Press.

MAGÜTA. 2014. Site oficial. http://museumaguta.com.br/

MoA-MUSEUM OF ANTHROPOLOGY (sem data). Musqueam weavers. Their stories. Vancouver: UBC Press.

MUSQUEAM PEOPLE. 1984. Musqueam comprehensive land claim. Preliminary report on musqueam land use and occupancy. Disponível em: http://www. musqueam.bc.ca/educational-materials 
2011. Musqueam first nation. A comprehensive sustainable community development plan. Vancouver: Musqueam First Nation.

- 2012. Musqueam comprehensive sustainable community development plan. CCP Workshop, AANDC. Mimeo. . 2014. "Musqueam. A living culture" (Site oficial). Disponível em: http:// www.musqueam.bc.ca/

NEARY, Kevin. 2005. First nations: developing relationships and partnerships. Victoria: British Columbia Museums Association.

NIMUENDAJÚ, Curt. 1952. The Tukuna. Berkeley \& Los Angeles: The University of California Press.

PACHECO DE OLIVEIRA, João. 1977. As facções e a ordem política em uma Reserva Ticuna. Dissertação de Mestrado, UNB. 1989. O nosso governo: os Ticuna e o Regime Tutelar. São Paulo: Marco Zero/CNPq.

· 1996. "Os caminhos para o Évare: a demarcação Ticuna". In: Carlos Alberto Ricardo (org.), Povos indígenas do Brasil, 1991-1995. São Paulo: Instituto Socioambiental. pp. 307-309.

- 1999. "O ofício do etnógrafo e a responsabilidade social do cientista". In: Ensaios em antropologia histórica. Rio de Janeiro: Editora UFRJ. pp. 211-263. . 2002. "Ação indigenista e utopia milenarista: as múltiplas faces de um processo de territorialização entre os Ticuna". In: Bruce Albert \& Alcida Rita Ramos (orgs.), Pacificando o branco: cosmologias do contato no norte-amazônico. São Paulo: Unesp. pp. 277-310. . 2012a. "A refundação do Museu Magüta: etnografia de um protagonismo indígena". In: Aline Montenegro Magalhães e Rafael Zamorano Bezerra (orgs.), Coleções e colecionadores. A polissemia das práticas. Rio de Janeiro: Museu Histórico Nacional. pp. 201-218.
. 2012b. "João Pacheco de Oliveira traça panorama dos indígenas do Brasil". In: Entrevista ao Globo Universidade', http://redeglobo.globo.com/ globouniversidade/noticia/2012/04/, 24/04/2012 PACHECO DE OLIVEIRA, João; SOUZA LIMA, Antonio Carlos de. 1988. "Os Ticuna no Alto Solimões e a luta pela terra: o massacre de São Leopoldo e o seu contexto". In: João Pacheco de Oliveira (org.), TERRA MAGUTA. Rio de Janeiro/ São Paulo: PETI/MAGUTA/CEDI. pp. 3-19. . 1991. "O massacre de São Leopoldo: mais uma investida contra os Ticuna". In: Povos indígenas no Brasil, 1987/88/89/90. São Paulo: CEDI. pp. 240-242.

PALADINO, Mariana. 2006. Estudar e experimentar na cidade: trajetórias sociais, escolarização e experiência urbana entre 'jovens' indígenas ticuna, Amazonas. Tese de Doutorado, PPGAS/MN/UFRJ.

PHILLIPS, Ruth. 2012a. "APEC at the Museum of Anthropology - the politics of site and the poetics of sight bite". In: Museum pieces. Towards the indigenization of Canadian museums. Montreal \& Kingston, London: McGill-Queen's University Press/ Ihaca. pp. 71-89.

. 2012b. "Moment of truth: the spirit sings as critical event and the exhibition inside it". In: Museum pieces. Towards the indigenization of Canadian museums. Montreal \& Kingston, London: McGill-Queen's University Press / Ithaca. pp. 48-70.

. 2012c. "Toward a dialogic paradigm. New models of collaborative curatorial practice". In: Museum pieces. Towards the indigenization of Canadian museums. Montreal \& Kingston, London: McGill-Queen's University Press/Ithaca. pp.185-204.

. 2012d. "A preface - by way of an Introduction". In: Museum pieces. Towards the indigenization of Canadian 
museums. Montreal \& Kingston, London: McGill-Queen's University Press/ Ithaca. pp. 3-22.

ROCA, Andrea. 2008. Objetos alheios, histórias compartilhadas: os usos do tempo em um museu etnográfico. Rio de Janeiro: DEMU-IPHAN.

- 2015. "Museus indígenas na Costa Noroeste do Canadá e nos Estados Unidos: colaboração, colecionamento e autorrepresentação". Revista de Antropologia da Universidade de São Paulo (no prelo). SHELTON, Anthony; MAYER, Carol E. (eds.). 2009. The museum of anthropology at the University of Bristish Columbia. Vancouver: D\&M Publishers Inc. 
Resumo

A partir de uma leitura comparativa sobre a agência indígena no Museu Magüta (primeiro museu indígena do Brasil, pertencente ao povo Ticuna, localizado em Benjamin Constant, Amazonas) e nas mostras do povo Musqueam no Museu de Antropologia da University of British Columbia (pioneiro na implementação do trabalho colaborativo com os povos indígenas, localizado em Vancouver, Canadá), este trabalho aborda modalidades coexistentes da chamada indigenização dos museus. Interessa-me distinguir as epistemologias e as políticas envolvidas na construção dos conteúdos indígenas desses espaços e sua autorrepresentação, problematizando a expressão "indigenização dos museus" e refletindo, ao mesmo tempo, sobre aquilo que se reconstrói, em termos dos cenários museológicos, após as situações coloniais.

Palavras-chave Museus indígenas, Indigenização dos museus, Ticuna, Musqueams, Autorrepresentação.

\section{Abstract}

Through a comparison between indigenous agency at the Magüta Museum (the first indigenous museum in Brazil, belongs to the Ticuna people, located in Benjamin Constant, Amazonas) and the exhibitions about the Musqueam Nation at the UBC Museum of Anthropology (that has pioneered collaboration in museum work with indigenous peoples, located in Vancouver, Canada), this work analyses coexistent modalities of the so-called indigenization of museums. It is interested in distinguishing the epistemologies and politics involved in the construction of the indigenous contents of these spaces and their self-representation, problematizing the expression "indigenization of museums" and reflecting, at the same time, about what is reconstructed after the colonial situations in terms of museum scenarios.

Key words Indigenous museums, Indigenization of museums, Ticuna, Musqueams, Self-representation. 